\title{
THE HISTORY OF MEDICINE IN CANADA*
}

\author{
by
}

\section{ROBERT SWAN}

Geographically, Canada suffers from gigantism. Its total area is almost $4,000,000$ square miles, lying north of the 49th parallel that separates us from the United States. Much of this land mass is almost uninhabitable, and so the majority of our $19,000,000$ people live along its southern borders, stretched out like a 4,000 mile ribbon from the Atlantic to the Pacific coasts.

This vast area has undergone almost four centuries of development and change, and to give an adequate description of its medical history is by no means easy. One can only select some of the highlights and curiosities of the story. Much cannot be included. The picture is further confused by the fact that pioneering doctors were not only medical men, but were, at the same time, pioneers in other fields, such as exploration, legislation, and also in allied sciences, politics and the law. One of our more notable examples was Sir Charles Tupper, a doctor who became Lieutenant Governor of Nova Scotia, then High Commissioner in London, and finally the Prime Minister of Canada. Osler said of Sir Charles, perhaps too sardonically, that he was 'really a politician first, and a medical practitioner only when stranded by the exigencies of the party'.

Any medical history must inevitably be fitted into its political framework and historical background, so please forgive my occasional digressions. To begin at the beginning: Canada was first sighted by Norsemen, around the year 1,000. Traces of their settlements have been well authenticated. In the thirteenth century, men from the Orkneys followed in their wake, but it was not until 1497 that we were officially 'discovered'. The brothers Cabot, sailing out of Bristol in the hope of finding a western route to China, found instead Newfoundland and Cape Breton, Nova Scotia, which they claimed in the name of Henry VII. He gave them ten pounds.

But the Cabots found only the fringe. Thirty-five years later, Jaques Cartier, sailing out of St. Malo under the more generous auspices of King Francis I, took his three ships hundreds of miles up the St. Lawrence river. He found first the Indian settlement of Hochelaga (now the city of Quebec) and 200 miles further inland, the village of Stadacona (now Montreal), and he laid claim to 'New France'. On the second of his three expeditions he spent the winter at Stadacona, and here, for the first time in our recorded history, disease raised its ugly head. Scurvy struck his crew. All but three of his 130 men were affected, and 27 of them died. On one a post-mortem was done, and the disease, as reported, sounds classic. Scurvy was new to the French, and its cause unknown. The situation was grave. Fortunately, an observant officer noticed that a native Indian, suffering from like symptoms, made a rapid recovery. It was then

* A paper read at the Symposium on The History of Medicine in the Commonwealth, organized by the Faculty of the History of Medicine and Pharmacy, and held at the Royal College of Physicians of London on 23 September 1966. 


\section{History of Medicine in Canada}

discovered that the local remedy was a decoction made from the sap and bark of a type of spruce tree. The brew saved Cartier and his remaining company, and the event was described in the $\log$ as a 'real and evident miracle'. The anti-scorbutic properties of the spruce tree were then for a long time lost, although they are still referred to in the Oxford Dictionary. About a century later, a British officer recognized the fact that citrus fruit containing vitamin $\mathrm{C}$, prevented the disease.

To return briefly to Cartier. During his winter at Stadacona, the Indian chief, Agouhenna by name, was afflicted with some form of paralysis. Cartier himself massaged the chief's limbs, evidently with some success, because the chief made him a gift of land, believed now to be site of the present University of McGill. Thus, physiotherapy came early to the New World, i.e. New France. Although there were British settlements along the Atlantic Coast, and later, others in the Hudson's Bay, the country, for the next 200 years, was predominantly and officially French.

At this point I must acknowledge Dr. J. J. Haegery's two-volume history of Canadian Medicine, published in 1928. It is an encyclopaedia, more than a book, and to me it has been a copious source of material for this paper. His opening sentence reads: 'Disease ranks with war as the scourge of mankind, and therefore has its particular historical significance'.

\section{INDIAN MEDICINE}

The medical history of our aboriginal tribes is fascinating. The North American plain and its coastlands was dotted with literally hundreds of tribes, large and small, peaceful and war-like. They were called Indians in the first place by the early explorers, who thought they had in fact discovered India.

The natives were regarded as ignorant savages by the Europeans. This was far from true. They were proud people and shy, and their atavistic talents were considerable. Each tribe had its medicine man, second only to the chief in authority, but he was not the curator of medical knowledge. His practices were shrouded in tribal mystery, more magical than medical, and based more on fear than on respect. One of his practices that was not 'shrouded in tribal mystery' was his insistence on prior payment before he would treat a case. Faith-healing was probably his stock in trade. The real care of the sick was undertaken by the women of the tribe, as so often happens.

Their skills were extraordinary. They knew, for instance, about blood-letting and cupping, the then contemporary European treatment for fevers. They could also set fractures with skill, and did successful amputations, using red-hot stones to coagulate bleeding points. They also had a wide variety of herbs and other forms of plant life to treat effectively the well-known problems of rheumatism, sore throats, constipation, diarrhoea, and flatulence. They also had diuretics and knew about poulticing. The most amazing thing of all was what they called 'ground medicine'. This was a lumpy fungus found in prairie soil, which, taken internally, worked wonderfully well in all manner of illnesses. It has subsequently been identified, in both Ottawa and in Washington, as the 'Tuckahoe Fungus', and one writer has speculated on its kinship to the well-known antibiotics Streptomycin and Terramycin, which were also derived from soil fungi. True or false, it makes a pretty speculation. 


\section{Robert Swan}

Midwifery amongst Indians was no problem. Babies were relatively small, and labours were easy. The infant 'papoose' was carried on its mother's back, wedged into a long pouch, which had a wooden backing bound with loops of cotton and lined with rabbit skins. This was also padded with sphagnum moss to absorb the excreta, and the moss could easily be cleaned and dried over the camp fire, thus saving the need of 'washing and drying of cloths for clouts'.

The Indian's treatment of drowning must be mentioned. Canoes overturn easily, so it was often a problem. The soaking victim was taken ashore and hung, head downwards, from the branch of a tree. Then they took a length of gut, tied at both ends, which was their usual vessel for carrying fats and oils. This was emptied, and filled with tobacco smoke which was blown into the lungs of the patient. If successful, his coughing brought up a lot of water, and normal breathing was restored.

The North American Indians may have contributed little to the summation of world medicine, but they in their time use imagination, folklore and common sense, and did remarkably well for themselves. The arrival of the white man was their undoing. Europeans brought with them not only pestilence, but also gunpowder and alcohol.

\section{THE EPIDEMICS}

In New France, in 1644 and 1648, our first hospitals (Hôtels Dieu), were established in Quebec and Montreal, subsidized by French aristocrats. The Duchesse d'Aiguillon, Richelieu's niece, sponsored this worthy cause for $\mathbf{4 0}$ years. These famous hospitals were opened and run by nursing nuns who emigrated from France, as one of them said, 'to trials, tribulations and a tomb'. They were women of such great gallantry and dedication that their contributions made to Canada's medical welfare are more than anyone can assess. Two hundred years later, Florence Nightingale is said to have been inspired by their example, and her nursing mission in the Crimea was the result.

Then also there were the Jesuits, those learned priests who roamed the wilderness to convert the natives to Christianity. They were scholars and frontiersmen as well. Through their knowledge and example, they contributed greatly to our early welfare, and sent back to their parent orders in France full accounts of their endeavours, so that our early history is thoroughly documented. Epidemics played a prominent part.

The earliest epidemic was smallpox, which originated from an outbreak in Spanish Mexico in 1635. It was a virulent and contagious form of the disease, and the native's immunity to it was pathetically non-existent. Over the next 200 years smallpox carried off an estimated 3,500,000 of the continental Indian population. Europeans appeared to have some immunity to the infection, but at the same time they seemed to carry it with them from place to place. As a result, the itinerant Jesuits who did what they could to help the afflicted, became very unwelcome visitors. Dr. Haegerty gives detailed accounts of not scores but hundreds of smallpox epidemics. One story is particularly horrid. He tells of a white trader who had suffered losses of equipment as the result of an Indian raid. His retribution was to invite the leaders of the Indian tribe concerned to smoke the pipe of peace. At the meeting he ceremoniously presented them with a keg of rum wrapped in a flag, with the injunction that they were not to 


\section{History of Medicine in Canada}

unwrap the keg until they got back to their encampment. The flag had been impregnated with the smallpox virus, and many members of the tribe died as a consequence. This must be one of the earliest examples of germ warfare.

There is, however, a happy ending to this sad story. In 1807 Edward Jenner heard of the devastations amongst the Indians, and he sent to the 'Chiefs of the Five Nations' an account of his theories and practice of vaccination against the disease. After a cautious start, vaccination was used extensively with great success. The chiefs wrote to Jenner to thank him for his miraculous advice, and I have seen a facsimile of their letter. It is written in fastidious English and is full of thanks. With it they sent a string of wampum. This is a belt of blue native beads, and the highest honour they could bestow upon their benefactor.

Not all the smallpox victims were Indians. There is one curious account of an outbreak amongst the nursing nuns of the Hôtel-Dieu in Quebec. For some strange reason their bodies were exhumed twenty-five years afterward. They were found to be in a perfect state of preservation. Their skins were clear and their joints supple, and for some even stranger reason their bodies were placed on public view.

Tales of epidemics are lugubrious and even dull, but they played a large part in our medical history. On the other hand, Canada has been spared such catastrophes as earthquakes, famines and floods (and also malaria) which have been the tragic fate of other countries. But we had a succession of strange epidemics. In 1710 , for instance, we had a considerable outbreak of yellow fever, as a result of the northern migration of the stegomyia mosquito from New Orleans. It was called 'Mal de Siam'. A decade later there was an outbreak of bubonic plague, brought to our shores by the rat-infested ships sailing from the Mediterranean. As a result of this our first quarantine laws were laid down in 1720 . In the nineteenth century tens of thousands of British, mainly Irish folk escaping from the famines, caught typhus en route, and in the year 1847 it was estimated that 30,000 poor wretches died at sea or soon after arrival. The nuns were hard put to it to deal with this terrible influx of disease, and my own great-great-grandfather tells in his autobiography how the civilian population of Montreal helped cope with the situation. He raised funds from the government and also by private subscription to build and run special huts that were to house the victims of both cholera and typhus. He says that nurses had to be 'bribed' to attend the patients, and that he himself was on duty 'morning, noon and night' to see that they did their duty. He himself was strongly impregnated with sulphur, in the belief that this would protect him from infection, together with the blessing of God. He adds, 'I was most mercifully preserved.'

We have even known leprosy. In 1828 a woman from St. Malo died of it, and over the ensuing few years there were over 200 further cases. The sufferers were consigned for the rest of their lives to lazaretti, and this stringent measure stopped further spread.

In the eighteenth century, in Nova Scotia, there was another curious epidemic, mainly amongst Scottish troops. It was called 'la mal de la Baie St. Paul'. This was a nicer way of describing what may have been extra-genital syphilis. Certainly it was a highly contagious disease, treated with corrosive sublimate of mercury, and later it was thought that some of the symptoms were due to the treatment rather than to the disease itself. 


\section{Robert Swan}

It is curious to note that the French law of the time actually prohibited the registration of the cause of death, although births and deaths were carefully documented. The idea was to prevent family embarrassment if death was the result of an unrespectable complaint.

Cholera was another unlikely predator. It began in 1832, and claimed 100,000 lives before it was finished. The situation became so grave that King William IV proclaimed a day of fasting for prayer and meditation in the hope of averting total annihilation of the colony. As with other infections, blood-letting was the usual treatment. It is interesting to note that intravenous saline was at that time in use to offset the dehydration. Unfortunately the first 20 cases so treated all died, so intravenous milk was used with less depressing results. In July of this year, in the Lancet, there was a description of the intravenous use of coconut milk which is currently in use in India, and is useful in post-operative cases. A Ceylonese colleague has told me that one uses the coconut milk at a certain stage of ripeness, and that its high potassium value is one of its assets.

As the nineteenth century drew to its unhealthy close the problem of tuberculosis became a national issue. The remaining Indians were particularly prone to it. Tuberculosis also attracted royal interest. In 1896 the Prince of Wales wrote to the GovernorGeneral, Lord Minto, expressing his concern 'for the health of Canadians'. His letter resulted in the formation of the Canadian Tuberculosis Association, which held its first meeting in Government House in Ottawa. Within two decades there were 30 sanatoria strewn across the land, built by government subsidy. In the past two decades the fight against tuberculosis has almost been won. In my student days, and perhaps even now, it was obligatory for every third-year student to spend a fortnight of his summer vacation in the provincial sanatorium. In a lovely countryside setting, we watched thoracoplasties being performed, read X-ray films, and saw the disease in all its stages.

This sad saga has left its mark on Canada. We are not really a nation of hypochondriacs, but we tend to take our health seriously. In what was once a sparsely populated country survival was an achievement and life and death attained undue significance. The consequence has been that Canadians contribute handsomely to medical charities and insure their health and their lives very heavily. Next year will see the start of a new national Medical Plan which will cost the government $\$ 600,000,000$ per year. Yet, basically, we are a healthy people.

\section{MEN IN MEDICINE}

Medical greatness seems to be of two types. There are the great practitioners of the art, men whose dedication and fine character inspire their patients and their students. Their names tend to fade too soon after their retirement from the scene. Then there are the others whose names do not die. This does not impute that they are men of lesser calibre, but their renown is associated with their dedication to ideas, their brilliance of invention, perhaps even their eccentricities.

One of the first Canadians of note was Michel Sarrazin, appointed in 1689 by Louis XIV to be royal physician to the garrison of Quebec. He remained in that office for forty years, and had a diversity of talents. Botanically inclined, he collected over 


\section{History of Medicine in Canada}

200 forms of plant life which he sent back to Paris. He also discovered a practical method for producing syrup and sugar from the maple tree, which is our traditional national confection. His zoological bent led him to write a definitive account of The Anatomy of the Beaver (and other animals), but it was his surgery that was most amazing. He successfully removed an unspecified number of breast tumours, mostly from nuns; surely a rare achievement in the late seventeenth century. Sarrazin's successor was Jean François Gaulthière, who discovered the therapeutic virtues of the oil of wintergreen, a well-known ingredient of most linaments, and the extract was named O1. Gaulthierium after him.

Preceding these gentlemen, almost by a century, was Dr. Estienne Bouchard, who made history of another kind. In 1655, in Ville-Marie (i.e. Montreal), Bouchard, a master surgeon, undertook to provide full medical care for a number of specified families for the absurdly small sum of $\$ 1.00$ per family per annum. The document is still to be seen in Montreal. This contract exempted ${ }_{i}$ Dr. Bouchard from providing his patients' medicines, and also from treating them for certain diseases. The exemptions included plague, smallpox, epilepsy and kidney stones. The agreement was renewable annually, which might easily be the dream of many a National Health practitioner today. Dr. Bouchard, on the other hand, could withdraw from the contract only if he had cured his patients from whatever ailment they may have had, which presumably kept him on his mettle.

There were other early examples of health insurance. The Reverend Mother Superior of the hospital of Ville-Marie made an agreement with two newly-arrived young French doctors to undertake the care of the patients on the wards of her hospital, in return for an agreed annual salary, based on the number of beds. There were two curious specifications. One was that ward rounds must be made daily, starting at 7 a.m., and the other was that the surgeons were not to allow their duties to interfere with those of the boy who was separately engaged as the hospital barber. The scalpel and the razor were not to be confused. This undertaking, made 300 years ago, was remarkably prophetic, and I am indebted to Dr. A. D. Kelly, Secretary General of the Canadian Medical Association, for a monograph about it.

Great rivalry prevailed between France and Britain for the possession of the colony, rivalry between races, people and political factions, with goodness and badness interwoven in the pattern. After over two centuries of French rule General Wolfe, in 1759, defeated his noble opponent Montcalm on the Plains of Abraham nearby Quebec, and Canada became a British possession. In the fighting both generals lost their lives.

A century later the Hudson's Bay Company sold its one million square miles of western territory to the British Government in what was called the 'biggest land deal in history'. Thus British Columbia on the west coast became linked with the newly formed prairie provinces, and the west in turn joined Upper and Lower Canada in the east, to become a national entity. Confederation took place in 1867, and last year Canada celebrated the centenary of its Constitution. Newfoundland remained as an independent British Colony until 1947, when it elected to join the Dominion as the tenth province. Legend has it that both Montreal and Toronto aspired to become the nation's capital, and Queen Victoria herself is said to have chosen instead 


\section{Robert Swan}

the then small village of Ottawa, equidistant between the two cities, to become the seat of government.

Now we return to the medical personalities who fit into the political setting. By the mid-seventeenth century more men with European qualifications were reaching our shores. The brain-drain had already begun; and Canadians themselves were going to Europe to study. Of these, one was Abraham Gesner, who studied in London under Abernethy and Astley Cooper. We might reasonably have expected him, on his return, to make a notable place in medicine, but Gesner was really a geologist at heart, and he discovered paraffin instead. His laboratory is reverently preserved by the Standard Oil Company. And petrol is well-nigh our life's blood.

Conditions of medical practice in those days were tough indeed. The physician needed 'the constitution of a horse, and the clothing of an Arctic explorer'. To some extent this is still true. And amongst the noble there were also the ignoble. In 1750, to improve medical standards, an ordnance was passed requiring practitioners to sit an examination in the presence of the King's Physician. Forty years later British parliament passed a law necessitating the proper licensing of doctors.

In spite of this legislation quackery was said to flourish. One writer described the doctors of the day as having a negligible knowledge of anatomy and the basic sciences, and that their "letters showed ignorance of the English language, and the inability to spell the simplest words'. One newspaper even published an appeal against quackery. In Kingston, Ontario, an advertisement denounced 'those, who, without one ray of science, presumed to thrust the created into the presence of their Creator'.

The empiricism of the time was amusingly shown in the shop window of a surgeon apothecary in St. John, New Brunswick. An advertisement read: 'Just Imported from London . . . in the brigantine Polly. Godfrey's Cordials, Bateman's Drops, Court Plaster, Friar's Balsam, Daffy's Elixir, and James' Powder,' and other intriguing sounding items. The earliest medical journals contained mainly meteorological tables and atmospheric variations.

In the early nineteenth century medical standards started to improve. 1823 saw the founding of the first medical faculty, at the University of Montreal, later to be McGill. Scotsmen tended to predominate on its staff, as they did so often in the faculties of the eleven other medical schools that were still to come into existence. In Toronto a Dr. Rolfe was the founder of the medical school in 1853 . He was a curious individual. He began by studying his medicine at both Guy's and St. Thomas's, and concurrently he took a degree in law. In 1812 he went to Canada and was called to the Bar. Evidently this was unrewarding, so he then studied Divinity and applied for orders. Somewhere en route he was involved in a political scandal and fled to the United States. He was reprieved some years later and returned to Toronto where he started the private tuition of medical students. His academy was the nucleus of the Toronto Medical Faculty. By the end of the century there were nine medical schools, and now there are twelve, which graduate about 850 doctors each year. Almost as many doctors immigrate from other countries to join their ranks. In spite of our traditional annual 25 per cent loss of graduates to the United States, Canada stands in danger of a surfeit of medical attention.

There were intermediate developments that were both heroic and amusing. In 1847 


\section{History of Medicine in Canada}

a Dr. Nelson of Toronto used ether anaesthesia on a dog. After a week's practice he felt himself sufficiently trained to use it in an operation for the removal of a two-pound uterine fibroid. But he himself was not the anaesthetist. The mask was being held by a dental colleague who, when the fibroid was out, took the opportunity of removing two of the patient's teeth. In 1848, within a few months of Simpson's first published article on chloroform, this anaesthetic was being used by a Dr. Holmes of Quebec. In those pioneer days deaths from anaesthetics were very rare, presumably because major surgery, as we know it, was still a very limited field. However, over the next three decades Lister's principles of antisepsis revolutionized both medicine and surgery, and the age-old horrors of infection began to fade. Several of Lister's dressers emigrated to Canada, and in 1894 the great man himself paid us a visit. One of his dressers, later to become Sir Thomias Roddick, was the creator of the Canadian Medical Council which sets uniform standards for medical education on a countrywide basis. The provinces are autonomous in the fields of medical education and legislation, and one's qualifying degree enables one to practise only within the borders of that province. In order to practise elsewhere in the country one therefore sits a second set of examinations, the 'Dominion Councils', soon after graduation. Most Canadian doctors are licentiates of this governing body.

In the latter half of the nineteenth century specialization began to appear. An ophthalmologist from Moorfields was probably the first. And in 1897 radiography was first used. It was in this period that our greatest physician flourished.

In 1849 William Osler was born, the youngest child of an Anglican churchman who 'dispensed medicine on the side'. Osler started his college life as a theologian, then switched to medicine and qualified at McGill in 1872. After two years in Europe he returned to Montreal where, for the next decade, he brilliantly collated his pathological findings with bedside teaching, in what was known as the Edinburgh method. Osler was also a classicist, and these biographical details I found in the foreword to a collection of his essays, published under the title Aequinimites. The foreword was written by Dr. Paul Dudley White, the doyen of modern cardiology.

Osler made no discoveries of great scientific importance, but his teaching methods made him famous. After a brief period in the University of Pennsylvania he went to Baltimore where he helped establish the hospital and medical school of Johns Hopkins University. There he published his monumental book, The Principles and Practice of Medicine which went through many editions. Once he said: 'To study the phenomena of disease without books is to sail an uncharted sea; while to study books without patients is not to go to sea at all'. In 1906 Osler left Baltimore to come to Oxford where he was Regius Professor of Medicine until his death in 1920. I regret having to make such an attenuated reference to a figure of such stature. That master of neurosurgery, Harvey Cushing of Boston, has written a biography of Osler that is generally regarded as a classic in medical literature.

In 1922 in Toronto Dr. Frederick Banting discovered insulin, Canada's most outstanding contribution to medicine. For this Dr. Banting was knighted, and in 1923 he was awarded the Nobel Prize, which honour was shared with his two junior colleagues, Dr. Charles Best and Dr. J. B. Collip. A grateful government built for them the Banting and Best Institute of Research, from which some quite notable 


\section{Robert Swan}

discoveries have emerged. In 1932 there was heparin which is still the anti-coagulant of choice when an immediate effect is required. By a curious coincidence, during the 'twenties the Ontario Veterinary College had discovered that a haemorrhagic disease of cattle was due to a toxic mould of sweet clover. This mould was synthesized, and another anti-coagulant, Dicoumerol, was the result. This, with heparin, is used in the long term treatment of thrombotic diseases. In the early thirties Dr. Collip was one of the discoverers of the hormone of the parathyroid gland, and not long afterward he described A.C.T.H., the precursor of the cortisone family. Canada was solely responsible for these major discoveries. In the reference books these notable Canadians all received due recognition, but it must also be pointed out that similar and parallel discoveries were being made in other countries at the same time.

We now salute a great woman of medicine, Dr. Maude Abbott of Montreal. Dr. Abbott's lifetime studies in the small but complex field of congenital heart disease made her name famous in the world of cardiology. This already legendary lady once lectured to our Pathology Class in Winnipeg. She spoke with serenity and simplicity and we were left with the feeling that we would never again be mystified by this notoriously complicated subject. At that time the Professor of Pathology at Manitoba was Dr. William Boyd who, during his twenty years of tenure, published his several text-books of pathology and endeared his name to medical students around the world. He wrote with delightful style, and still does.

Speaking of the number of editions of books, the Canadian award must surely go to a pioneer psychiatrist, Dr. Richard Bucke (1837-1902). Apart from his reformation work in the management of the insane he also fathered weird-sounding psychological and philosophical theories described in a book called Cosmic Consciousness. This was published in 1902, the year before he died. It has since gone through 21 editions, the most recent in 1962. He prophesied some of the social and economic revolutions that have since taken place, and also alterations in aerial navigation.

A few names remain to be dropped very briefly. Many other names must go unmentioned, regretfully. Names apart, I have also omitted references to integral parts of the national medical fabric, such as the histories of the hospitals, medical schools, and nursing organizations. But time forbids.

One more recent name is that of Dr. Hans Selye, the Montreal scientist, whose theories of the alarm reaction and the adaptation syndrome have attracted world-wide interest. Dr. Wilder Penfield, from his spectacular Neurological Institute at McGill, made outstanding contributions to our knowledge of epilepsy and temporal lobe function. This magnificent building was financed by the Rockefeller Foundation (which Osler helped to found) and which has contributed generously to Canadian research ever since. In the field of anaesthesia Dr. Easson Brown was the discoverer of Ethylene, which he used for the first time on his colleague Dr. Fred Banting, of insulin fame. In 1951 the west produced, in Saskatchewan, the first Cobalt-60 unit for cancer therapy.

Now I must desist; but not before thanking two of my former mentors, Dr. Earle Scarlett of Calgary, and Dr. Lennox Bell of Winnipeg who kindly sent me material for this paper. I must thank also Dr. Charles Roland, a Canadian who is now one of the senior editors of the Journal of the American Medical Association. 


\section{History of Medicine in Canada}

He is a keen historian, and he sent me reprints, encouragement and good advice.

Dr. Ross Mitchell's book, Medicine in Manitoba, has been of great interest and help.

Canadians have much to be proud of, and we are proud. At the same time, we are members not only of a Commonwealth of Nations but also of a Commonwealth of Medicine, the world-wide fraternity of doctors that ignores political considerations. We can only strive to give our patients, when they fall ill, a better than even chance of recovery. 